\title{
Harnessing the wealth of Chinese scientific literature: schistosomiasis research and control in China Qin Liu ${ }^{1}$, Li-Guang Tian ${ }^{1}$, Shu-Hua Xiao ${ }^{1}$, Zhen Qi ${ }^{1}$, Peter Steinmann², Tippi K Mak², Jürg Utzinger ${ }^{2}$ and Xiao-Nong Zhou*1
}

Address: ${ }^{1}$ National Institute of Parasitic Diseases, Chinese Center for Disease Control and Prevention, Shanghai 200025, PR China and 2Department of Public Health and Epidemiology, Swiss Tropical Institute, P.O. Box, CH-4002 Basel, Switzerland

Email: Qin Liu - liuqin0901@sohu.com; Li-Guang Tian - jztlg@126.com; Shu-Hua Xiao - shxiao4@hotmail.com; Zhen Qi - bearqi@21cn.com; Peter Steinmann - peter.steinmann@unibas.ch; Tippi K Mak - tippi.mak@unibas.ch; Jürg Utzinger - juerg.utzinger@unibas.ch; XiaoNong Zhou* - ipdzhouxn@sh163.net

* Corresponding author

Published: 30 September 2008

Emerging Themes in Epidemiology 2008, 5:19 doi:10.1186/1742-7622-5-19

This article is available from: http://www.ete-online.com/content/5/1/19

(c) 2008 Liu et al; licensee BioMed Central Ltd.

This is an Open Access article distributed under the terms of the Creative Commons Attribution License (http://creativecommons.org/licenses/by/2.0), which permits unrestricted use, distribution, and reproduction in any medium, provided the original work is properly cited.

\begin{abstract}
The economy of China continues to boom and so have its biomedical research and related publishing activities. Several so-called neglected tropical diseases that are most common in the developing world are still rampant or even emerging in some parts of China. The purpose of this article is to document the significant research potential from the Chinese biomedical bibliographic databases. The research contributions from China in the epidemiology and control of schistosomiasis provide an excellent illustration. We searched two widely used databases, namely China National Knowledge Infrastructure (CNKI) and VIP Information (VIP). Employing the keyword "Schistosoma" (血服虫) and covering the period 1990-2006, we obtained 10,244 hits in the CNKI database and 5,975 in VIP. We examined 10 Chinese biomedical journals that published the highest number of original research articles on schistosomiasis for issues including languages and open access. Although most of the journals are published in Chinese, English abstracts are usually available. Open access to full articles was available in China Tropical Medicine in 2005/2006 and is granted by the Chinese Journal of Parasitology and Parasitic Diseases since 2003; none of the other journals examined offered open access. We reviewed (i) the discovery and development of antischistosomal drugs, (ii) the progress made with molluscicides and (iii) environmental management for schistosomiasis control in China over the past 20 years. In conclusion, significant research is published in the Chinese literature, which is relevant for local control measures and global scientific knowledge. Open access should be encouraged and language barriers removed so the wealth of Chinese research can be more fully appreciated by the scientific community.
\end{abstract}




\section{Introduction}

In this thematic series of Emerging Themes in Epidemiology, Fung provides a general overview of Chinese biomedical journals, and a focus on specialized journals in epidemiology, preventive medicine and public health [1]. Moreover, Fung examines two of the six core mainland Chinese biomedical bibliographic databases - WanFang Data and iLib - and emphasises that the Chinese interface of Google Scholar provides a convenient entry point to search for Chinese articles. His analysis complements a recent investigation by Xia $e t$ al. who studied the accessibility, content and form of five major Chinese biomedical databases, namely (i) Biomedical Literature Database (CBM), (ii) Chinese Medical Current Content (CMCC), (iii) China National Knowledge Infrastructure (CNKI) Medicine and Hygiene Section, (iv) VIP Information (VIP), and (v) the above-mentioned WanFang Data [2]. Finally, Fung discusses the prospects and challenges of English language journals published in China, including issues of language publication bias and quality, and concludes that "Chinese journals are a mine of epidemiological information that is yet to be explored by the outside world" [1].

The purpose of our article is to illustrate that the Chinese literature is indeed a treasure house of biomedical knowledge. One of the most prominent examples is the discovery of the antimalarial properties of artemisinin (the active ingredient derived from the herb Artemisia annua) in the early 1970 s by Chinese scientists [3,4]. Comprehensive investigations of the chemistry and synthesis of artemisinin and its derivatives, assessment of the antimalarial efficacy in different animal models, toxicity and mechanism of action studies, and clinical trials involving over 2000 patients infected with Plasmodium were carried out in the 1970s and published in specialized Chinese journals. In 1982, the key findings were summarized and published in English in a special issue of the Journal of Traditional Chinese Medicine [5-8]. However, the real significance of these findings only became clear to the clinical and scientific community outside of China in the mid1980s when a review article entitled "Qinghaosu (artemisinin): an antimalarial drug from China" was published in Science [9]. In the meantime, Klayman's review has been cited 878 times (Thomson ISI Web of Science, accessed 20 March 2008), and hundreds of millions of people have been treated with an artemisinin derivative worldwide [10].

Here, we focus on research contributions on the epidemiology and control of schistosomiasis from the Chinese literature. First, we provide a brief overview of the global situation of schistosomiasis, and then summarize the public health significance and achievements made in the control of the "God of Plague" in China over the past half century [11]. We then put forward the most important Chinese journals that publish original research pertaining to schistosomiasis. We also address the issue of accessibility, which is paramount for discovering the resources within the Chinese biomedical literature. For illustrative purposes, two examples are given: (i) the discovery and development of antischistosomal drugs, and (ii) advances made with molluscicides and environmental management for schistosomiasis control. Given China's track record in controlling schistosomiasis japonica $[11,12]$, and in view of new initiatives underway to control schistosomiasis in Africa [13], researchers and policy-makers alike should look towards accessing the long-standing vast Chinese experience to help guide strategies from local to national and global control.

\section{Chinese databases: the lay of the land}

At present, more than 10 Chinese biomedical databases are available online. The two largest and most widely used databases for searching and retrieving scientific information in biomedicine are CNKI and VIP as shown in Table 1. CNKI embodies more than 8,200 journals, of which 2,460 are considered 'core' journals with the highest reputation. Disciplines include the natural sciences (e.g. agriculture and biology), medical sciences, engineering, humanities, philosophy and the social sciences. Most researchers in these fields consider CNKI as the "Chinese PubMed", as it is the most comprehensive database in these disciplines. CNKI is updated continuously and, since April 2006, provides access to all issues for about half of the journals referenced. At present, CNKI includes over 17.5 million citations.

VIP cites articles from more than 8,000 major Chinese and English periodicals that are published in China. Arti-

Table I: Overview of the main Chinese biomedical bibliographic databases.

\begin{tabular}{lllll}
\hline Database & Year launched & Number of journals covered & Open access & Web-site \\
\hline CNKI & 1999 & Over 8,200 full-text journals, including I,707 medical journals & No & $\underline{\text { http://www.cnki.net/index.htm }}$ \\
VIP & 2000 & Over 8,000 full-text journals, including I,675 medical journals & No & $\underline{\text { http://www.cqvip.com }}$ \\
Wan Fang & 2000 & Over 8,000 full-text journals, including I,004 medical journals & No & $\underline{\text { http://www.wanfangdata.com.cn/ }}$ \\
CBM & 1995 & Over I,600 biomedical journals & No & $\underline{\text { http://cbmwww.imicams.ac.cn/ }}$ \\
CMCC & 1994 & Over I,200 biomedical journals & No & $\underline{\text { http://www.mlpla.cn:8082/trscbf/gjhj/ }}$ \\
\hline
\end{tabular}


cles are available from the late 1980s onwards and cover natural sciences, including agriculture, medical sciences and engineering, as well as the humanities, philosophy and the social sciences. Whilst CNKI provides access to full text articles in portable document format (PDF) and China Academic Journals (CAJ) format, VIP has full text articles in PDF only.

Access to articles referenced in either of these databases requires a subscription but abstracts may be downloaded without charge. For individual users, CNKI and VIP even accept payment by Chinese mobile phone services and some "pay-per-download" cards. The latter operates in a similar fashion to a telephone card, hence provides an account and password to log in to the database for subsequent downloading of a limited number of full text articles. Institutional subscriptions held by companies, research institutions and universities permit unlimited access to these databases.

To retrieve an article, the databases can be queried by field tags, including subject, title, keyword, abstract, author, affiliation of the corresponding author, journal name, year of publication, and so forth. Searches can also be performed on previous search results and field tags can be combined using the Boolean operators "AND" and "OR". The operator "NOT" is only used in VIP.

\section{Schistosomiasis in the Chinese literature}

\section{Setting the stage: the global and Chinese contexts}

Schistosomiasis remains one of the most prevalent parasitic diseases in the world with more than 200 million individuals infected, of whom over half suffer from related morbidity [14]. Whilst the global burden of schistosomiasis has been estimated at 1.7 to 4.5 million disability-adjusted life years $[15,16]$, new research suggests this is a considerable underestimation of the 'true' burden of schistosomiasis $[17,18]$. However, schistosomiasis is a so-called neglected tropical disease, because it primarily affects poor rural communities in developing countries $[19,20]$.

Schistosomiasis japonica has been known in China for over two millennia, but the first case report from China was not published until 1905 [21]. Towards the end of the 1940 s, the central government of China recognized the intolerable burden of schistosomiasis and initiated a national control programme $[11,12]$. The third national sampling survey, completed in 2004, enrolled more than 250,000 individuals from 239 villages from the seven provinces where Schistosoma japonicum remains endemic. Human prevalence ranged from $0.3 \%$ in Jiangsu province to $4.2 \%$ in Hunan province. Extrapolating these data, the total number of infected individuals in China was estimated at 726,112 in 2004 [22]. This estimate translates to a reduction of $16.1 \%$ when compared with the previous national survey carried out in 1995, and dramatically lower than the 10 million Chinese estimated to be infected in the mid-1950s [11,12].

\section{Searching Chinese biomedical databases}

To illustrate how to search and make use of the Chinese scientific databases, we provide the following example.

The keyword "Schistosoma" (血婴) was used to search the CNKI and VIP databases. Publication dates were set from 1990 to 2006 . The results were imported into the reference management programme EndNote version 9 (Thomson ResearchSoft, Stamford, USA). The articles were stratified by journals, and sorted in descending order, i.e. number of articles published in the specified time frame. The journals were subdivided into core and non-core journals. The name, year when the journal was launched, language (abstract and main text) and open access status were recorded.

Additionally, we performed a content analysis and grouped the identified articles according to the following categories: (i) development, validation and application of new tools, (ii) epidemiology, (iii) control, and (iv) other schistosomiasis-related research. This analysis was stratified into two time periods: (i) 1990-1999 and (ii) 2000-2006.

\section{Key Chinese journals for schistosomiasis research}

For the period 1990-2006, we obtained 10,244 hits in the CNKI and 5,975 hits in the VIP databases when using the keyword "Schistosoma" (血服虫). Figure 1 shows the number of hits per year for the two bibliographic databases. Three points are worth highlighting. First, more references were retrieved by the CNKI database compared with VIP in each year, but this gap has narrowed over time. Second, after a sharp increase in the number of hits on the CNKI database from $1993(\mathrm{n}=255)$ to $1994(\mathrm{n}=$ $645)$, the annual number of hits in subsequent years remained relatively stable (602-838). Third, there was a gradual increase in the number of hits per year in the VIP database from 96 hits in 1990 to 585 hits in 2006.

In the 17-year period we examined, the 10 leading Chinese journals publishing original research on schistosomiasis were (i) Chinese Journal of Schistosomiasis Control (Zhongguo Xue Xi Chong Bing Fang Zhi Za Zhi), (ii) Journal of Tropical Diseases and Parasitology (Re Dai Bing Yu Ji Sheng Chong Xue), (iii) Chinese Journal of Parasitology and Parasitic 


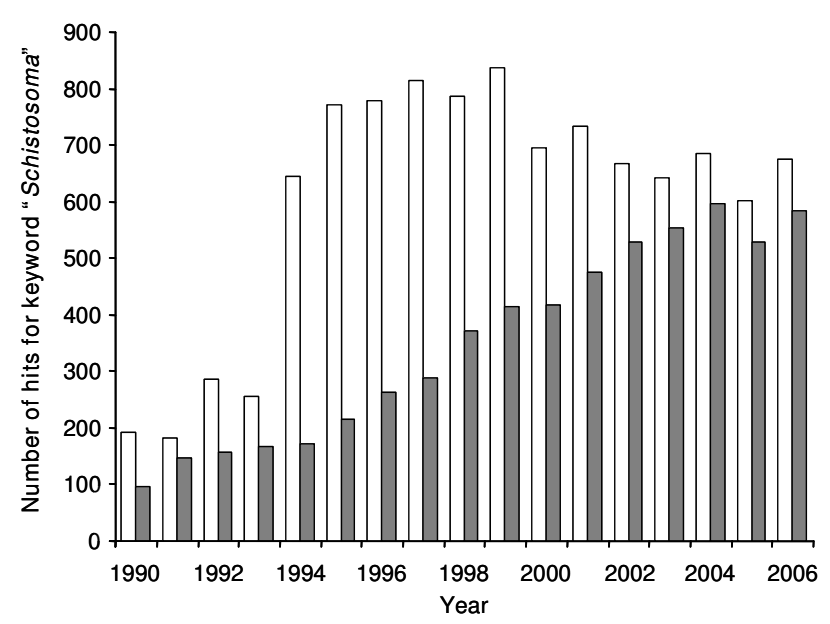

Figure I

Number of hits for the keyword "Schistosoma" 向吸中

(1) in two widely used Chinese databases: CNKI (white bars) and VIP (shaded bars) from 1990-2006.

Diseases (Zhongguo Ji Sheng Chong Xue Yu Ji Sheng Chong Bing Za Zhi), (iv) Parasitoses and Infectious Diseases (Ji Sheng Chong Bing Yu Gan Ran Xing Ji Bing, as well as its former title between 1994-2002, Journal of Practical Parasitic Diseases, Shi Yong Ji Sheng Chong Bing Za Zhi), (v) Journal of Pathogen Biology (Zhongguo Bing Yuan Sheng Wu Xue $\mathrm{Za} Z \mathrm{Zhi}$, as well as its former title between 1988-2005, Chinese Journal of Parasitic Disease Control, Zhongguo Ji Sheng Chong Bing Fang Zhi Za Zhi), (vi) Chinese Journal of Zoonoses (Zhongguo Ren Shou Gong Huan Bing Xue Bao, as well as its former title between 1985-2005, Zhongguo Ren Shou Gong Huan Bing Za Zhi), (vii) International Journal of Medical Parasitic Diseases (Guo Ji Yi Xue Ji Sheng Chong Bing Za Zhi, as well as its former title between 1994-2005, Foreign Medicine Sciences Parasitic Diseases, Guo Wai Yi Xue Ji Sheng Chong Bing Fen Ce), (viii) Journal of Public Health and Preventive Medicine (Gong Gong Wei Sheng Yu Yu Fang Yi Xue, as well as its former title between 1994-2004, Hubei Journal of Preventive Medicine, Hubei Yu Fang Yi Xue Za Zhi), (ix) Practical Preventive Medicine (Shi Yong Yu Fang Yi Xue), and (x) China Tropical Medicine (Zhongguo Re Dai Yi Xue). The cumulative numbers of Schistosoma-specific articles that were published by these journals were 2,954, 858, $674,607,458,354,262,217,180$ and 82, respectively. Original research articles accounted for $70.8-90.8 \%$ of the total share of published work in nine of the 10 examined journals, whereas in the International Journal of Medical Parasitic Diseases the respective fraction was only $30.2 \%$. China Tropical Medicine was launched in 2001, which partly explains its lower quantity of published papers.
These 10 journals except the International Journal of Medical Parasitic Diseases and the Journal of Public Health and Preventive Medicine are all core journals and they comply with high academic standards. Submitted manuscripts, particularly original research and reviews, are usually peer-reviewed by at least two external referees. The Chinese Journal of Parasitology and Parasitic Diseases, which is hosted by the National Institute of Parasitic Diseases, Chinese Center for Disease Control and Prevention in Shanghai, for example, convenes six editorial meetings per year to come forward with final editorial decisions on which manuscripts to publish in the six issues per year. Articles usually contain Chinese and English summaries. Commencing in 2005, the International Journal of Medical Parasitic Diseases routinely publishes full-text English articles. The main body of some articles in Chinese Journal of Parasitic Disease Control, Chinese Journal of Parasitology and Parasitic Diseases and China Tropical Medicine are also published in English. The main body of articles published in the remaining six journals are usually only available in Chinese 1.

At present, only one of these 10 journals is indexed in PubMed under its Chinese name, Zhongguo Ji Sheng Chong Xue Yu Ji Sheng Chong Bing Za Zhi (Chinese Journal of Parasitology and Parasitic Diseases; indexed on PubMed since 1987). China Tropical Medicine is indexed on PubMed under its English name. Moreover, the following four journals are available from the 'Journals Database' in NCBI: (i) Chinese Journal of Schistosomiasis Control (Zhongguo Xue Xi Chong Bing Fang Zhi Za Zhi); (ii) Chinese Journal of Parasitology and Parasitic Diseases (Zhongguo Ji Sheng Chong Xue Yu Ji Sheng Chong Bing Za Zhi); (iii) Journal of Pathogen Biology (Zhongguo Bing Yuan Sheng Wu Xue Za Zhi) and (iv) Chinese Journal of Zoonoses (Zhongguo Ren Shou Gong Huan Bing Xue Bao). When searching PubMed for the term "Schistosoma" and restricting the search to the journal "Zhongguo Ji Sheng Chong Xue Yu Ji Sheng Chong Bing $\mathrm{Za} Z \mathrm{Zhi}^{\prime}$ and setting the temporal limits to 1990-2006, the total number of articles retrieved was 302 , which translates to $44.8 \%$ of those found on the Chinese databases. None of the 10 Chinese journals examined here are yet included in the ISI Web of Knowledge. However, since the 1990s China has developed a similar citation database, namely the Chinese Science Citation Database, which contained already approximately 1,000 Chinese journals in 2001 [23]. With regard to open access, this feature was available for China Tropical Medicine in 2005 and 2006 via the website [24]. The Chinese Journal of Parasitology and Parasitic Diseases allowed open access sine 2003 directly on the journal website [25].

\section{Content analysis}

The retrieved Schistosoma-specific articles from the 10 leading Chinese journals were classified into four main 
groups, namely (i) new tools (e.g. development, validation and application of novel diagnostics, drugs and vaccines), (ii) epidemiology (e.g. epidemiological surveys, monitoring and surveillance), (iii) control (e.g. chemotherapy, health education, water supply and sanitation, and integrated control measures), and (iv) other research. Moreover, a temporal analysis was carried out, and we compared the relative frequencies of different research topics between the time periods 1990-1999 and 2000-2006.

Table 2 shows that in the 1990s, a total of 3,240 papers pertaining to different aspects of schistosomiasis were published in the 10 journals. One of the selected journals (China Tropical Medicine) was only launched in the new millennium, so the analysis of publications in the 1990s was based on nine rather than 10 journals. The development, validation and application of new tools and epidemiological research were the most important fields of endeavour, accounting for $26.8 \%$ and $29.5 \%$ of the original research articles published, respectively. With regard to new tools, diagnostics (11.9\%) and drugs (9.7\%) had a considerably higher share of the total publications than vaccines $(5.2 \%)$. Publications with a focus on control accounted for $21.2 \%$. The remaining publications (22.4\%) pertained to other aspects of schistosomiasis research. Between journals, the proportions of each field of Schistosoma-related publications varied. For example, the Chinese Journal of Zoonoses published a large number of schistosomiasis- research articles that pertained to new tools (49.0\%). Parasitoses and Infectious Diseases had the highest proportion of epidemiological research on schistosomiasis (45.2\%). The two journals Practical Preventive Medicine and Journal of Public Health and Preventive Medicine had the highest share of articles dealing with schistosomiasis control: $39.2 \%$ and $38.6 \%$, respectively.

In the period 2000-2006, a total of 2,448 articles with an emphasis on schistosomiasis had been published in the 10 selected Chinese journals (Table 3 ). We found slightly higher proportions of published research pertaining to the development, validation and application of new tools (30.5\%) and epidemiology (26.6\%) when compared with the 1990s. On the other hand, the frequency of articles that focused on schistosomiasis control issues had not changed much $(21.2 \%$ in the 1990 s and $21.7 \%$ in $2000-$ 2006). Generally, the proportion of articles on different aspects of schistosomiasis published by the individual journals were similar between the 1990s and the new millennium. Our results suggest that the journals examined here place particular emphasis on specific topics, and hence develop specific niches. Parasitoses and Infectious Diseases, for example, primarily covered epidemiological research on schistosomiasis $(56.6 \%)$, whereas in the Chinese Journal of Zoonoses and China Tropical Medicine, more than half of the schistosomiasis-related articles focused on the development, validation and application of new tools.

\section{Harnessing the Chinese literature}

Discovery, development and use of antischistosomal drugs

A total of 328 articles were retrieved in the CNKI database when we searched for publications pertaining to the discovery, development and use of antischistosomal drugs. A significant amount of research focused on praziquantel, an antischistosomal drug discovered in the mid-1970s by Bayer in Germany $[26,27]$. The first clinical use of praziquantel in China dates back to the late 1970s [28]. Since then, praziquantel has become the drug of choice for the control of schistosomiasis worldwide $[15,29]$. More than 50 million treatment courses have been administered in China and comprehensive reviews have recognised the significant contributions from Chinese clinicians and scientists towards the optimization of praziquantel use for individual treatment and community-based morbidity control $[30,31]$. The large-scale deployment of praziquantel, particularly during the 10-year World Bank Loan Project (WBLP) (1992-2001) to control schistosomiasis in China, significantly reduced the morbidity due to $S$. japonicum [32]. To date, there is no clear evidence of clinically relevant resistance to praziquantel and there are basically no alternative drugs available, although perhaps praziquantel analogues could be developed. An important limitation of praziquantel is that it lacks activity against the young developing stages of S. japonicum [33].

In 1980, Chinese scientists discovered that artemisinin, in addition to its antimalarial activity, also exhibited antischistosomal properties [34]. Studies suggested that artemisinin and its derivatives (artemether and artesunate) could kill the early developmental stages of the parasite, thus preventing the development of egg-laying adult worms, and hence preventing the associated morbidity from the immunological reactions to schistosome eggs trapped in the host tissue. In 2000, the key findings of 20 years of laboratory research and the evidence generated from clinical trials were published in English in one of the leading international parasitology journals [35]. Subsequently, the data were also reviewed and published in the Chinese Journal of Schistosomiasis Control, of course in Chinese [36]. In view of the artemisinins exhibiting highest activity against juvenile $S$. japonicum worms, ensuing research was aimed at developing the artemisinins as chemoprophylactic agents against schistosomiasis. Early administration of artemether was highly efficacious in preventing patent infections among flood relief workers exposed to schistosome-infested water [37]. Importantly, this body of research stimulated scientists outside China to assess the effect of the artemisinins on the other two major human schistosome species, i.e. S. haematobium 
Table 2: Total number of Schistosoma-specific articles published from 1990-1999 in the 10 leading Chinese journals publishing original schistosomiasis research articles in China, by major research topic

\begin{tabular}{|c|c|c|c|c|c|c|c|c|c|c|c|}
\hline \multirow[t]{2}{*}{ Journal } & \multirow{2}{*}{$\begin{array}{l}\text { Total } \\
\text { articles }\end{array}$} & \multicolumn{3}{|c|}{ New tools } & \multirow[t]{2}{*}{ Epidemiology } & \multicolumn{5}{|c|}{ Control } & \multirow{2}{*}{$\begin{array}{l}\text { Other } \\
\text { research }\end{array}$} \\
\hline & & Diagnostics & Drugs & Vaccines & & Clinical issues & Chemotherapy & $\begin{array}{l}\text { Health } \\
\text { education }\end{array}$ & $\begin{array}{l}\text { Water } \\
\text { supply and } \\
\text { sanitation }\end{array}$ & $\begin{array}{l}\text { Integrated } \\
\text { control }\end{array}$ & \\
\hline $\begin{array}{l}\text { Chinese Journal } \\
\text { of } \\
\text { Schistosomiasis } \\
\text { Control }\end{array}$ & 1576 & $\begin{array}{l}183 \\
(11.6 \%)\end{array}$ & $\begin{array}{l}152 \\
(9.6 \%)\end{array}$ & $\begin{array}{l}63 \\
(4.0 \%)\end{array}$ & $\begin{array}{l}502 \\
(31.9 \%)\end{array}$ & $\begin{array}{l}39 \\
(2.5 \%)\end{array}$ & $\begin{array}{l}146 \\
(9.3 \%)\end{array}$ & $\begin{array}{l}35 \\
(2.2 \%)\end{array}$ & $\begin{array}{l}17 \\
(1.1 \%)\end{array}$ & $\begin{array}{l}78 \\
(4.9 \%)\end{array}$ & $\begin{array}{l}361 \\
(22.9 \%)\end{array}$ \\
\hline $\begin{array}{l}\text { Journal of } \\
\text { Tropical } \\
\text { Diseases and } \\
\text { Parasitology }\end{array}$ & 520 & $\begin{array}{l}56 \\
(10.8 \%)\end{array}$ & $\begin{array}{l}45 \\
(8.6 \%)\end{array}$ & $\begin{array}{l}28 \\
(5.4 \%)\end{array}$ & $\begin{array}{l}203 \\
(39.0 \%)\end{array}$ & $\begin{array}{l}14 \\
(2.7 \%)\end{array}$ & $\begin{array}{l}39 \\
(7.5 \%)\end{array}$ & $\begin{array}{l}16 \\
(3.1 \%)\end{array}$ & $\begin{array}{l}50 \\
(9.6 \%)\end{array}$ & $\begin{array}{l}38 \\
(7.3 \%)\end{array}$ & $\begin{array}{l}31 \\
(6.0 \%)\end{array}$ \\
\hline $\begin{array}{l}\text { Chinese Journal } \\
\text { of Parasitology } \\
\text { and Parasitic } \\
\text { Diseases }\end{array}$ & 320 & $\begin{array}{l}29 \\
(9.1 \%)\end{array}$ & $\begin{array}{l}41 \\
(12.8 \%)\end{array}$ & $\begin{array}{l}3 \\
(0.9 \%)\end{array}$ & $\begin{array}{l}48 \\
(15.0 \%)\end{array}$ & $\begin{array}{l}7 \\
(2.1 \%)\end{array}$ & $\begin{array}{l}4 \\
(1.3 \%)\end{array}$ & $\begin{array}{l}3 \\
(0.9 \%)\end{array}$ & $\begin{array}{l}3 \\
(0.9 \%)\end{array}$ & $\begin{array}{l}4 \\
(1.3 \%)\end{array}$ & $\begin{array}{l}178 \\
(55.6 \%)\end{array}$ \\
\hline $\begin{array}{l}\text { Parasitoses and } \\
\text { Infectious } \\
\text { Diseases }\end{array}$ & 292 & $\begin{array}{l}51 \\
(17.5 \%)\end{array}$ & $\begin{array}{l}12 \\
(4.1 \%)\end{array}$ & $\begin{array}{l}3 \\
(1.0 \%)\end{array}$ & $\begin{array}{l}132 \\
(45.2 \%)\end{array}$ & $\begin{array}{l}18 \\
(6.2 \%)\end{array}$ & $\begin{array}{l}7 \\
(2.4 \%)\end{array}$ & $\begin{array}{l}16 \\
(5.5 \%)\end{array}$ & 0 & $\begin{array}{l}24 \\
(8.2 \%)\end{array}$ & $\begin{array}{l}29 \\
(9.9 \%)\end{array}$ \\
\hline $\begin{array}{l}\text { Journal of } \\
\text { Pathogen } \\
\text { Biology }\end{array}$ & 166 & $\begin{array}{l}15 \\
(9.0 \%)\end{array}$ & $\begin{array}{l}29 \\
(17.5 \%)\end{array}$ & $\begin{array}{l}17 \\
(10.2 \%)\end{array}$ & $\begin{array}{l}23 \\
(13.9 \%)\end{array}$ & $\begin{array}{l}4 \\
(2.4 \%)\end{array}$ & $\begin{array}{l}8 \\
(4.8 \%)\end{array}$ & $\begin{array}{l}3 \\
(1.8 \%)\end{array}$ & $\begin{array}{l}6 \\
(3.6 \%)\end{array}$ & $\begin{array}{l}4 \\
(2.4 \%)\end{array}$ & $\begin{array}{l}57 \\
(34.3 \%)\end{array}$ \\
\hline $\begin{array}{l}\text { Chinese Journal } \\
\text { of Zoonoses }\end{array}$ & 114 & $\begin{array}{l}15 \\
(13.1 \%)\end{array}$ & $\begin{array}{l}14 \\
(12.2 \%)\end{array}$ & $\begin{array}{l}27 \\
(23.7 \%)\end{array}$ & $\begin{array}{l}2 \\
(1.8 \%)\end{array}$ & $\begin{array}{l}13 \\
(11.4 \%)\end{array}$ & $\begin{array}{l}3 \\
(2.6 \%)\end{array}$ & $\begin{array}{l}2 \\
(1.8 \%)\end{array}$ & $\begin{array}{l}2 \\
(1.8 \%)\end{array}$ & $\begin{array}{l}\text { I } \\
(0.9 \%)\end{array}$ & $\begin{array}{l}35 \\
(30.7 \%)\end{array}$ \\
\hline $\begin{array}{l}\text { Journal of Public } \\
\text { Health and } \\
\text { Preventive } \\
\text { Medicine }\end{array}$ & 101 & $\begin{array}{l}17 \\
(16.8 \%)\end{array}$ & $\begin{array}{l}11 \\
(10.9 \%)\end{array}$ & $\begin{array}{l}2 \\
(2.0 \%)\end{array}$ & $\begin{array}{l}23 \\
(22.8 \%)\end{array}$ & $\begin{array}{l}17 \\
(16.8 \%)\end{array}$ & 6 & $\begin{array}{l}4 \\
(4.0 \%)\end{array}$ & $\begin{array}{l}2 \\
(2.0 \%)\end{array}$ & $\begin{array}{l}10 \\
(9.9 \%)\end{array}$ & $\begin{array}{l}9 \\
(8.9 \%)\end{array}$ \\
\hline $\begin{array}{l}\text { Practical } \\
\text { Preventive } \\
\text { Medicine }\end{array}$ & 97 & $\begin{array}{l}16 \\
(16.5 \%)\end{array}$ & $\begin{array}{l}7 \\
(7.2 \%)\end{array}$ & $\begin{array}{l}3 \\
(3.1 \%)\end{array}$ & $\begin{array}{l}22 \\
(22.7 \%)\end{array}$ & $\begin{array}{l}10 \\
(10.3 \%)\end{array}$ & $\begin{array}{l}10 \\
(10.3 \%)\end{array}$ & $\begin{array}{l}5 \\
(5.2 \%)\end{array}$ & $\begin{array}{l}2 \\
(2.1 \%)\end{array}$ & $\begin{array}{l}11 \\
(11.3 \%)\end{array}$ & $\begin{array}{l}\text { II } \\
\text { (II.3\%) }\end{array}$ \\
\hline $\begin{array}{l}\text { International } \\
\text { Journal of } \\
\text { Medical } \\
\text { Parasitic } \\
\text { Diseases }\end{array}$ & 54 & $\begin{array}{l}3 \\
(5.6 \%)\end{array}$ & $\begin{array}{l}4 \\
(7.4 \%)\end{array}$ & $\begin{array}{l}22 \\
(40.7 \%)\end{array}$ & $\begin{array}{l}2 \\
(3.7 \%)\end{array}$ & 0 & (1.9\%) & 0 & 0 & $\begin{array}{l}5 \\
(9.2 \%)\end{array}$ & $\begin{array}{l}17 \\
(31.5 \%)\end{array}$ \\
\hline $\begin{array}{l}\text { China Tropical } \\
\text { Medicine }\end{array}$ & n.a. & n.a. & n.a. & n.a. & n.a. & n.a. & n.a. & n.a. & n.a. & n.a. & n.a. \\
\hline Total & 3240 & $\begin{array}{l}385 \\
(11.9 \%)\end{array}$ & $\begin{array}{l}315 \\
(9.7 \%)\end{array}$ & $\begin{array}{l}168 \\
(5.2 \%)\end{array}$ & $\begin{array}{l}957 \\
(29.5 \%)\end{array}$ & $\begin{array}{l}122 \\
(3.8 \%)\end{array}$ & $\begin{array}{l}224 \\
(6.9 \%)\end{array}$ & $\begin{array}{l}84 \\
(2.6 \%)\end{array}$ & $\begin{array}{l}82 \\
(2.5 \%)\end{array}$ & $\begin{array}{l}175 \\
(5.4 \%)\end{array}$ & $\begin{array}{l}728 \\
(22.4 \%)\end{array}$ \\
\hline
\end{tabular}

n.a. not applicable/not available

and S. mansoni, first in the laboratory, followed by clinical trials (for a recent review see [38]).

\section{Molluscicides and environmental management}

From the CNKI database, a total of 290 articles pertaining to molluscicides and environmental management for schistosomiasis control were retrieved. Different approaches regarding the possible elimination of the intermediate host snail (genus: Oncomelania) have been reported, including biological methods (e.g. introduction of competitor snails), chemical control (e.g. use of molluscicides) and environmental management. With regard to molluscicides, niclosamide is the most widely used product in China [39-41]. A number of new compounds have been developed in China and their molluscicidal properties evaluated in the laboratory and in small pilot studies but, thus far, these compounds have not been applied on a wider scale in the field. The compounds include bromoacetamide, nicotinanilide, metaldehyde, thiocyclohexane oxalate and 1,3-bis-sodium thiosulfate-2- dimethylaminopropane [42-44]. One of the compounds, namely 40\% META liquid (a metaldehyde product licensed by Lonza Ltd., Basel, Switzerland) shows a promising molluscicidal effect against Oncomelania with low toxicity to fish. Hence this compound holds particular promise for the control of intermediate host snails, and thus warrants further investigation [45]. Moreover, some compounds impede the snail's sensory system and permit an increased area of softbody exposure, thus enhancing molluscicidal activities when combined with other agents [46]. Therefore, several new molluscicide formulations, including powder formulations and suspension concentrate formulations were developed to increase the efficacy of niclosamide.

Chinese researchers have also tested plant extracts from Arca catectu, Camellia oleosa, Eucalyptus camaldulensis, Jatropha curcas, Leonurus artemisia, Rhododendron sinensis, among others, for their molluscicidal properties [47-49]. Most of these plant extracts showed potential effect 
Table 3: Total number of Schistosoma-specific articles published from 2000-2006 in the 10 leading Chinese journals publishing original schistosomiasis research articles in China, by major research topic

\begin{tabular}{|c|c|c|c|c|c|c|c|c|c|c|c|}
\hline \multirow[t]{2}{*}{ Journal } & \multirow[t]{2}{*}{ Total articles } & \multicolumn{3}{|c|}{ New tools } & \multirow[t]{2}{*}{ Epidemiology } & \multicolumn{5}{|c|}{ Control } & \multirow{2}{*}{$\begin{array}{l}\text { Other } \\
\text { research }\end{array}$} \\
\hline & & Diagnostics & Drugs & Vaccines & & $\begin{array}{l}\text { Clinical } \\
\text { issues }\end{array}$ & Chemotherapy & $\begin{array}{l}\text { Health } \\
\text { education }\end{array}$ & $\begin{array}{l}\text { Water supply } \\
\text { and sanitation }\end{array}$ & $\begin{array}{l}\text { Integrated } \\
\text { control }\end{array}$ & \\
\hline $\begin{array}{l}\text { Chinese Journal } \\
\text { of } \\
\text { Schistosomiasis } \\
\text { Control }\end{array}$ & 1154 & $\begin{array}{l}128 \\
(11.1 \%)\end{array}$ & $\begin{array}{l}134 \\
(11.6 \%)\end{array}$ & $\begin{array}{l}40 \\
(3.5 \%)\end{array}$ & $\begin{array}{l}382 \\
(33.1 \%)\end{array}$ & $\begin{array}{l}117 \\
(10.1 \%)\end{array}$ & $\begin{array}{l}28 \\
(2.4 \%)\end{array}$ & $\begin{array}{l}31 \\
(2.7 \%)\end{array}$ & $\begin{array}{l}16 \\
(1.4 \%)\end{array}$ & $\begin{array}{l}67 \\
(5.8 \%)\end{array}$ & $\begin{array}{l}211 \\
(18.3 \%)\end{array}$ \\
\hline $\begin{array}{l}\text { Chinese Journal } \\
\text { of Parasitology } \\
\text { and Parasitic } \\
\text { Diseases }\end{array}$ & 230 & $\begin{array}{l}23 \\
(10.0 \%)\end{array}$ & $\begin{array}{l}21 \\
(9.1 \%)\end{array}$ & $\begin{array}{l}17 \\
(7.4 \%)\end{array}$ & $\begin{array}{l}33 \\
(14.3 \%)\end{array}$ & $\begin{array}{l}6 \\
(2.6 \%)\end{array}$ & 0 & 0 & 0 & $\begin{array}{l}5 \\
(2.2 \%)\end{array}$ & $\begin{array}{l}125 \\
(54.3 \%)\end{array}$ \\
\hline $\begin{array}{l}\text { Parasitoses and } \\
\text { Infectious } \\
\text { Diseases }\end{array}$ & 205 & $\begin{array}{l}28 \\
(13.6 \%)\end{array}$ & $\begin{array}{l}11 \\
(5.4 \%)\end{array}$ & $\begin{array}{l}2 \\
(1.0 \%)\end{array}$ & $\begin{array}{l}116 \\
(56.6 \%)\end{array}$ & $\begin{array}{l}12 \\
(5.9 \%)\end{array}$ & $\begin{array}{l}5 \\
(2.4 \%)\end{array}$ & $\begin{array}{l}16 \\
(7.8 \%)\end{array}$ & $\begin{array}{l}\text { I } \\
(0.5 \%)\end{array}$ & $\begin{array}{l}10 \\
(4.9 \%)\end{array}$ & $\begin{array}{l}4 \\
(2.0 \%)\end{array}$ \\
\hline $\begin{array}{l}\text { Journal of } \\
\text { Tropical } \\
\text { Diseases and } \\
\text { Parasitology }\end{array}$ & 186 & $\begin{array}{l}20 \\
(10.8 \%)\end{array}$ & $\begin{array}{l}17 \\
(9.1 \%)\end{array}$ & $\begin{array}{l}10 \\
(5.4 \%)\end{array}$ & $\begin{array}{l}69 \\
(37.1 \%)\end{array}$ & $\begin{array}{l}16 \\
(8.6 \%)\end{array}$ & $\begin{array}{l}5 \\
(2.7 \%)\end{array}$ & $\begin{array}{l}2 \\
(1.1 \%)\end{array}$ & $\begin{array}{l}12 \\
(6.4 \%)\end{array}$ & $\begin{array}{l}18 \\
(9.6 \%)\end{array}$ & $\begin{array}{l}17 \\
(9.1 \%)\end{array}$ \\
\hline $\begin{array}{l}\text { Chinese Journal } \\
\text { of Parasitic } \\
\text { Disease Control }\end{array}$ & 179 & $\begin{array}{l}12 \\
(6.7 \%)\end{array}$ & $\begin{array}{l}20 \\
(11.1 \%)\end{array}$ & $\begin{array}{l}36 \\
(20.1 \%)\end{array}$ & $\begin{array}{l}30 \\
(16.8 \%)\end{array}$ & $\begin{array}{l}14 \\
(7.8 \%)\end{array}$ & $\begin{array}{l}2 \\
(1.1 \%)\end{array}$ & $\begin{array}{l}5 \\
(2.8 \%)\end{array}$ & $\begin{array}{l}4 \\
(2.2 \%)\end{array}$ & $\begin{array}{l}9 \\
(5.0 \%)\end{array}$ & $\begin{array}{l}47 \\
(26.3 \%)\end{array}$ \\
\hline $\begin{array}{l}\text { Chinese Journal } \\
\text { of Zoonoses }\end{array}$ & 156 & $\begin{array}{l}16 \\
(10.3 \%)\end{array}$ & $\begin{array}{l}7 \\
(4.5 \%)\end{array}$ & $\begin{array}{l}68 \\
(43.6 \%)\end{array}$ & $\begin{array}{l}10 \\
(6.4 \%)\end{array}$ & $\begin{array}{l}3 \\
(1.9 \%)\end{array}$ & $\begin{array}{l}\text { I } \\
(0.6 \%)\end{array}$ & 0 & 0 & $\begin{array}{l}3 \\
(1.9 \%)\end{array}$ & $\begin{array}{l}48 \\
(30.8 \%)\end{array}$ \\
\hline $\begin{array}{l}\text { International } \\
\text { Journal of } \\
\text { Medical } \\
\text { Parasitic } \\
\text { Diseases }\end{array}$ & $|4|$ & $\begin{array}{l}15 \\
(10.6 \%)\end{array}$ & $\begin{array}{l}13 \\
(9.2 \%)\end{array}$ & $\begin{array}{l}35 \\
(24.8 \%)\end{array}$ & $\begin{array}{l}15 \\
(10.6 \%)\end{array}$ & $\begin{array}{l}3 \\
(2.1 \%)\end{array}$ & 0 & 0 & $\begin{array}{l}2 \\
(1.4 \%)\end{array}$ & $\begin{array}{l}8 \\
(5.7 \%)\end{array}$ & $\begin{array}{l}50 \\
(35.5 \%)\end{array}$ \\
\hline $\begin{array}{l}\text { Journal of Public } \\
\text { Health and } \\
\text { Preventive } \\
\text { Medicine }\end{array}$ & 71 & $\begin{array}{l}12 \\
(16.9 \%)\end{array}$ & $\begin{array}{l}5 \\
(7.0 \%)\end{array}$ & $\begin{array}{l}2 \\
(2.8 \%)\end{array}$ & $\begin{array}{l}21 \\
(29.6 \%)\end{array}$ & $\begin{array}{l}3 \\
(4.2 \%)\end{array}$ & $\begin{array}{l}4 \\
(5.6 \%)\end{array}$ & $\begin{array}{l}2 \\
(2.8 \%)\end{array}$ & $\begin{array}{l}3 \\
(4.2 \%)\end{array}$ & $\begin{array}{l}16 \\
(22.5 \%)\end{array}$ & $\begin{array}{l}3 \\
(4.2 \%)\end{array}$ \\
\hline $\begin{array}{l}\text { China Tropical } \\
\text { Medicine }\end{array}$ & 67 & $\begin{array}{l}2 \\
(3.0 \%)\end{array}$ & $\begin{array}{l}8 \\
(11.9 \%)\end{array}$ & $\begin{array}{l}25 \\
(37.3 \%)\end{array}$ & $\begin{array}{l}15 \\
(22.4 \%)\end{array}$ & $\begin{array}{l}3 \\
(4.5 \%)\end{array}$ & 0 & I $1.5 \%)$ & $\begin{array}{l}3 \\
(4.5 \%)\end{array}$ & $\begin{array}{l}3 \\
(4.5 \%)\end{array}$ & $\begin{array}{l}7 \\
(10.4 \%)\end{array}$ \\
\hline $\begin{array}{l}\text { Practical } \\
\text { Preventive } \\
\text { Medicine }\end{array}$ & 59 & $\begin{array}{l}9 \\
(15.2 \%)\end{array}$ & $\begin{array}{l}6 \\
(10.2 \%)\end{array}$ & $\begin{array}{l}5 \\
(8.5 \%)\end{array}$ & $\begin{array}{l}14 \\
(23.7 \%)\end{array}$ & $\begin{array}{l}8 \\
(13.6 \%)\end{array}$ & $\begin{array}{l}6 \\
(10.2 \%)\end{array}$ & 0 & (I.7\%) & $\begin{array}{l}6 \\
(10.2 \%)\end{array}$ & $\begin{array}{l}4 \\
(6.8 \%)\end{array}$ \\
\hline Total & 2448 & $\begin{array}{l}265 \\
(10.8 \%)\end{array}$ & $\begin{array}{l}242 \\
(9.9 \%)\end{array}$ & $\begin{array}{l}240 \\
(9.8 \%)\end{array}$ & $\begin{array}{l}652 \\
(26.6 \%)\end{array}$ & $\begin{array}{l}238 \\
(9.7 \%)\end{array}$ & $\begin{array}{l}51 \\
(2.1 \%)\end{array}$ & $\begin{array}{l}57 \\
(2.3 \%)\end{array}$ & $\begin{array}{l}42 \\
(1.7 \%)\end{array}$ & $\begin{array}{l}145 \\
(5.9 \%)\end{array}$ & $\begin{array}{l}516 \\
(21.1 \%)\end{array}$ \\
\hline
\end{tabular}

against Oncomelania, but due to low yields extracted from raw plant material, it is unlikely that these compounds will play an important role for mollusciciding programmes in the near future unless the active ingredient can be isolated and synthesized $[48,49]$.

A considerable number of articles focused on environmental management and their role for enhancing the national schistosomiasis control programme in China. Prominent examples are integration of environmental management with agriculture activities, e.g. alteration of crops planted, reclamation of land and plantations to eliminate snail habitats [50]. Integration of environmental management with water resources development projects has also been carried out, e.g. cement lining of irrigation canals, installation of sinks to obstruct snail dispersal, and construction of flood gates in the connection areas of main irrigation canals or rivers. Integration of environmental management with forestry projects is another example, e.g. planting trees in the marshlands to change the ecology of snail habitats and to discourage buffaloes from grazing on the marshland, and establishing new forests in the mountainous areas [51,52]. Finally, integration of environmental management with agricultural projects has also been implemented, e.g. construction of fish ponds, rearrangement of irrigation systems and establishment of drainage systems.

In the lake regions of Anhui, Hubei, Hunan, Jiangsu and Jiangxi provinces, a diversity of ecological and environmental measures were employed and their effect on reducing or even eliminating the intermediate host snails and interrupting the transmission of $S$. japonicum was assessed. The interventions consisted of (i) constructing fish ponds, (ii) digging new ditches and filling of infested ones, (iii) reclaiming land and planting trees, (iv) earth burying, (v) concreting over ditches and (vi) combining different environmental management interventions $[53,54]$. The results of these investigations suggested that environmental management provides effective measures not only for in reducing or even eliminating snail habitats, but also for in markedly reducing the prevalence of 
human schistosomiasis. Comprehensive agricultural development and environment modifications as described, in conjunction with chemotherapy targeting both humans and domestic animals, demonstrated success in significantly reducing the prevalence of human schistosomiasis in China [50-53]. In particular, new hydraulic technologies for preventing the spread of Oncomelania during flooding have been explored and integrated into the local control programmes in the lake region, based on an enhanced understanding of snail ecology and hydrology [51,55-59].

In the mountainous areas of Sichuan and Yunnan provinces, environmental control measures such as constructing reservoirs, and modifying the complex environment showed some success in reducing the number of intermediate host snails and lowering the human infection prevalence. However, there is considerable concern that the damming of the Yangtze River, particularly due to the Three Gorges Dam, will lead to the emergence or re-emergence of schistosomiasis [54]. This once again calls for rigorous monitoring and surveillance.

The development of special types of latrines with three sinks for the treatment of 'night-soil' and the production of biogas, as well as issuing new national guidelines for drinking water supply are also worth noting. Indeed, Chinese research has shown that setting aside human faecal matter intended for 'night-soil' for at least 15 days reduced miracidia hatching of schistosome eggs by up to $99.8 \%$ [50].

\section{China's influence on local schistosomiasis control strategies and global policy}

China established a national leading group for schistosomiasis control at the central government level early on. From the second half of the 1950s onwards, leading groups were established at different administrative levels, e.g. at provincial, county and township levels. Members of these leading groups were drawn from the health, agriculture and the water sectors, and hence intersectoral collaboration was fostered. For the implementation of schistosomiasis control measures - with an initial focus on snail control - large numbers of local residents were mobilized to carry out these tasks $[59,60]$.

Numerous provincial and county anti-schistosomiasis control stations have been created in China. In the 1980s, for example, approximately 16,000 professionals were responsible for controlling schistosomiasis across the country. The policy at the time emphasised prevention and aimed at a comprehensive control approach, readily adapted to the different eco-epidemiological settings. Hence, multiple control measures were implemented simultaneously and the ultimate objective was to inter- rupt transmission in an efficient and cost-effective manner [55].

In the mid-1980s, an expert committee of the World Health Organization (WHO) endorsed a new schistosomiasis control strategy that shifted the focus from transmission control to morbidity control. Simply put, it emphasised that people, rather than snails, cause schistosomiasis. By adopting the new strategy, more emphasis was placed on health education, large-scale screening and chemotherapy, access to clean water and improved sanitation. In China, however, snail control was never abandoned and intersectoral collaboration between health, education, and agriculture and water authorities remained a key feature of the national schistosomiasis control programme $[11,52]$. The central role that China placed on health education to reduce the risk of human transmission is reflected in the number of people involved; China employed 40,000 staff in health education for schistosomiasis control in 1995 [58]. Information, education and communication materials were developed and validated, and key messages for the prevention of schistosomiasis were broadcasted through China's mass media. In the 1990s more than 2 million textbooks for the prevention and control of schistosomiasis were distributed in primary and secondary schools in China's schistosomeendemic areas. Monitoring of these activities revealed that the coverage rate of health education for schistosomiasis control among schoolchildren approached 100\% [56,57].

The last 15 years of schistosomiasis control in China can be summarized as follows. First, the objectives of the control programme gradually shifted from morbidity control to transmission control and, finally, transmission interruption [58-60]. The WBLP funds for schistosomiasis control, which ran from 1992-2001, were an important component of the "Eighth Five-Year Plan" (1991-1995) and the "Ninth Five-Year Plan" (1996-2000) of China's national schistosomiasis control programme [32]. The WBLP emphasised morbidity control using praziquantel, and continued to adopt disease surveillance, health education and applied research [52]. In 1998, an important document entitled "A plan of action on surveillance and consolidation for schistosomiasis in transmission interrupted areas" was produced by the Chinese health authorities [61]. In 2004, "An outline of the mid-term and longterm programme for schistosomiasis control and prevention in China" was issued by the State Council, and in 2006, the "National Regulation of Schistosomiasis Control" was published by the State Department of China [62].

Medical breakthroughs developed first in China, as exemplified in the case of the artemisinins against malaria and schistosomiasis [38], have made a huge impact in the 
research community and on global health. China has a track record of developing and implementing truly integrated control measures against schistosomiasis, but much of China's decades of knowledge have yet to become fully accessible and be realised outside of the country.

\section{Conclusion}

China's social and economic advancement, its bountiful talent and the embrace of new technologies have all fuelled scientific research activities along with the development of important biomedical bibliographic databases. The potential of the Chinese literature to advance biomedical research has been stressed more than a decade ago [63], but challenges for the Chinese journals have also been highlighted $[64,65]$. As our example in schistosomiasis research illustrates, the number of Schistosomarelated articles alone from China increased from 193 in 1990 to 676 in 2006 in the CNKI database and from 96 to 585 in the VIP database over the same time period. From these two databases we retrieved and analysed more than 3,000 articles focusing on original schistosomiasis research and determined the leading 10 Chinese journals in the field of schistosomiasis research. Most of the articles were published in Chinese, often with an English summary.

We have highlighted significant contributions from the Chinese literature, exemplified by two key areas of schistosomiasis research: (i) drug discovery, and (ii) molluscicides and environmental management for integrated control approaches. Research from China has enhanced our antischistosomal drug and molluscicidal armamentarium and the understanding of the local epidemiology and control of schistosomiasis. We have used one area of research as an example to illustrate how the Chinese scientific literature can influence global health and research. Unfortunately, there are often long delays in the international dissemination of important knowledge from nonEnglish speaking countries such as China to the wider research community. Concerted efforts should be made and innovative methods developed to promote open, rapid and accurate access to new knowledge and to overcome language barriers.

\section{Abstracts in non-English languages}

The abstract of this paper has been translated into the following languages by the following translators (names in brackets):

- Chinese - simplified characters (Dr. Qin Liu and Prof. Xiao-Nong Zhou) [see Additional file 1]

- Chinese - traditional characters (Dr. Qin Liu and Prof. Xiao-Nong Zhou) [see Additional file 2]
- French (Mr. Philip Harding-Esch) [see Additional file 3]

- German (Dr. Peter Steinmann) [see Additional file 4]

- Spanish (Ms. Annick Borquez) [see Additional file 5]

\section{Additional Table I}

Characteristics of the 10 Chinese journals publishing the highest number of original schistosomiasis research articles were summarized in Additional Table 1. [see Additional file 6]

\section{Competing interests}

The authors declare that they have no competing interests.

\section{Authors' contributions}

QL retrieved the data from the Chinese biomedical databases, carried out the quantitative analysis and content analysis and contributed to drafting the manuscript. LGT assisted with the data retrieval and analysis of the data. SHX interpreted the data on drug discovery and development and drafted this part of the manuscript. ZQ assisted in the data retrieval and analysis of the data. PS assisted in the interpretation of the data and the drafting and revision of the manuscript. TKM contributed to the idea of this manuscript and revised the manuscript. JU conceived the manuscript, checked and interpreted the data, drafted and revised the manuscript. XNZ conceived the manuscript, checked and interpreted the data, drafted and revised the manuscript, and is the guarantor of the paper. All authors read and approved the final manuscript.

\section{Additional material}

\section{Additional File 1}

Abstract in Chinese - Simplified characters.

Click here for file

[http://www.biomedcentral.com/content/supplementary/1742-

7622-5-19-S1.pdf]

\section{Additional File 2}

Abstract in Chinese - traditional characters.

Click here for file

[http://www.biomedcentral.com/content/supplementary/1742-

7622-5-19-S2.pdf]

\section{Additional File 3}

Abstract in French.

Click here for file

[http://www.biomedcentral.com/content/supplementary/1742-

7622-5-19-S3.pdf]

\section{Additional File 4}

Abstract in German.

Click here for file

[http://www.biomedcentral.com/content/supplementary/1742-

7622-5-19-S4.pdf] 


Additional File 5
Abstract in Spanish.
Click here for file
[http://www.biomedcentral.com/content/supplementary/1742-
7622-5-19-S5.pdf]
Additional File 6
Additional Table 1. Characteristics of the 10 Chinese journals publishing
the highest number of original schistosomiasis research articles.
Click here for file
[http://www.biomedcentral.com/content/supplementary/1742-
7622-5-19-S6.pdf]

\section{Acknowledgements}

We are grateful to Mr. Isaac C.-H. Fung and three external referees for their series of constructive and useful comments. We acknowledge financial support from various funding bodies, namely the National Natural Science Foundation of China (grant no. 30590373), the UNICEF/UNDP/World Bank/WHO Special Programme for Research and Training in Tropical Diseases (TDR) (grant no. A30298), the Ministry of Science and Technology (grant no. 2004BA7I8BI2), the Freiwillige Akademische Gesellschaft, Basel (to P. Steinmann), the Commission for Research Partnership with Developing Countries (through the SDC-sponsored programme "Jeunes Chercheurs"; to P. Steinmann), the Janggen-Pöhn Stiftung for a personal stipend for the final year of P. Steinmann's PhD, and the Swiss National Science Foundation (grant no. PPOOB-I02883; to J. Utzinger).

\section{References}

I. Fung ICH: Chinese journals: a guide for epidemiologists. Emerg Themes Epidemiol 2008, 5:20.

2. Xia J, Wright J, Adams CE: Five large Chinese biomedical bibliographic databases: accessibility and coverage. Health Info Libr J 2008, 25(I):55-6I.

3. $\mathrm{Li} \mathrm{Y}, \mathrm{Wu} \mathrm{YL}$ : An over four millennium story behind qinghaosu (artemisinin) - a fantastic antimalarial drug from a traditional Chinese herb. Curr Med Chem 2003, 10:2197-2230.

4. Wang MW, Hao XJ, Chen $\mathrm{KX}$ : Biological screening of natural products and drug innovation in China. Philos Trans $R$ Soc Lond B Biol Sci 2007, 362: I093-I I05.

5. China Cooperative Research Group on Qinghaosu and its Derivatives as Antimalarials: Studies on the toxicity of qinghaosu and its derivatives. J Tradit Chin Med 1982, 2:31-38.

6. China Cooperative Research Group on Qinghaosu and its Derivatives as Antimalarials: Chemical studies on qinghaosu (artemisinine). J Tradit Chin Med 1982, 2:3-8.

7. China Cooperative Research Group on Qinghaosu and its Derivativesas Antimalarials: Antimalarial efficacy and mode of action of qinghaosu and its derivatives in experimental models. J Tradit Chin Med 1982, 2:17-24.

8. China Cooperative Research Group on Qinghaosu and its Derivatives as Antimalarials: Clinical studies on the treatment of malaria with qinghaosu and its derivatives. J Tradit Chin Med 1982, 2:45-50.

9. Klayman DL: Qinghaosu (artemisinin): an antimalarial drug from China. Science 1985, 228:1049-1055.

10. Haynes RK: From artemisinin to new artemisinin antimalarials: biosynthesis, extraction, old and new derivatives, stereochemistry and medicinal chemistry requirements. Curr Top Med Chem 2006, 6:509-537.

II. Utzinger J, Zhou XN, Chen MG, Bergquist R: Conquering schistosomiasis in China: the long march. Acta Trop 2005, 96:69-96.

12. Zhou XN, Wang LY, Chen MG, Wu XH, Jiang QW, Chen XY, Zheng J, Utzinger J: The public health significance and control of schistosomiasis in China - then and now. Acta Trop 2005, 96:97-105.
13. Fenwick A, Rollinson D, Southgate V: Implementation of human schistosomiasis control: challenges and prospects. Adv Parasitol 2006, 61 1:567-622.

14. Steinmann P, Keiser J, Bos R, Tanner M, Utzinger J: Schistosomiasis and water resources development: systematic review, metaanalysis, and estimates of people at risk. Lancet Infect Dis 2006, 6:4I I-425.

15. WHO: Prevention and control of schistosomiasis and soiltransmitted helminthiasis: report of a WHO expert committee. World Health Organ Tech Rep Ser 2002, 9 I 2: I-57.

16. WHO: The world health report 2004: changing history Geneva: World Health Organization; 2004.

17. King $\mathrm{CH}$, Dickman K, Tisch DJ: Reassessment of the cost of chronic helmintic infection: a meta-analysis of disabilityrelated outcomes in endemic schistosomiasis. Lancet 2005, 365: $156 \mid-1569$

18. Jia TW, Zhou XN, Wang $X H$, Utzinger J, Steinmann $P, W u X H$ : Assessment of the age-specific disability weight of chronic schistosomiasis japonica. Bull World Health Organ 2007, 85:458-465.

19. Hotez PJ, Molyneux DH, Fenwick A, Kumaresan J, Ehrlich Sachs S, Sachs JD, Savioli L: Control of neglected tropical diseases. $N$ Engl I Med 2007, 357:1018-1027.

20. Keiser J, Utzinger J: Advances in the discovery and development of novel trematocidal drugs. Expert Opin Drug Discov 2007, 2(I):S9-S23.

21. Logan OT: A case of dysentery in Hunan province caused by the trematode Schistosoma japonicum. China Med Missionary J 1905, 1 9:243-245.

22. Zhou XN, Guo JG, Wu XH, Jiang QW, Zheng J, Dang $H$, Wang $X H$, $\mathrm{Xu}$ J, Zhu HQ, Wu GL, et al.: Epidemiology of schistosomiasis in the People Republic of China, 2004. Emerg Infect Dis 2007, I3: |470-1476.

23. Leydesdorff L, Bihui J: Mapping the Chinese Science Citation Database in terms of aggregated journal-journal citation relations. J Am Soc Inf Sci Technol 2005, 56: I469-I479.

24. China Tropical Medicine [http://journal.shouxi.net/qikan/ guokanll zzxq.php?id=|2I]

25. Chinese Journal of Parasitology and ParasiticDiseases [http:/ /www.jsczz.cn/cn/dqml.asp]

26. Seubert J, Pohlke R, Loebich F: Synthesis and properties of praziquantel, a novel broad spectrum anthelmintic with excellent activity against schistosomes and cestodes. Experientia 1977, 33:1036-1037.

27. Groll E: Praziquantel. Adv Pharmacol Chemother 1984, 20:219-238.

28. Yang Y, Shen GR, Mei YS, Zhang CH, Ying LZ, You BY, Dong YQ, Fu $\mathrm{S}$, Wu HM, Qie YD, et al.: Study on the new drug praziquantel for schistosomiasis. New Med I98I, I 2:5-9.

29. Utzinger J, Keiser J: Schistosomiasis and soil-transmitted helminthiasis: common drugs for treatment and control. Expert Opin Pharmacother 2004, 5:263-285.

30. Chen MG: Use of praziquantel for clinical treatment and morbidity control of schistosomiasis japonica in China: a review of 30 years' experience. Acta Trop 2005, 96:168-176.

31. Xiao SH: Development of antischistosomal drugs in China, with particular consideration to praziquantel and the artemisinins. Acta Trop 2005, 96: I53-167.

32. Chen XY, Wang LY, Cai JM, Zhou XN, Zheng J, Guo JG, Wu XH, Engels D, Chen MG: Schistosomiasis control in China: the impact of a I0-year World Bank Loan Project (I992-200I). Bull World Health Organ 2005, 83:43-48.

33. Xiao SH, Yue WJ, Yang YQ, You JQ: Susceptibility of Schistosoma japonicum to different developmental stages to praziquantel. Chin Med J 1987, 100:759-768.

34. Chen DJ, Fu LF, Shao PP, Wu FZ, Fan CZ, Shu H, Ren CX, Sheng XL: Experimental studies on antischistosomal activity of qinghaosu. Zhong Hui Yi Xue Zha Zhi 1980, 60:422-425.

35. Xiao $\mathrm{SH}$, Booth $M$, Tanner $M$ : The prophylactic effects of artemether against Schistosoma japonicum infections. Parasitol Today 2000, I 6: I22-126.

36. Xiao SH: Study on the prevention and cure efficacy of artemether against schistosomiasis. Chin J Schisto Cont 2005, 17:310-320.

37. Song $Y$, Xiao SH, Wu W, Zhang S, Xie HQ, Xu XP, Hu XY, Cui Q, Chen MG, Zheng J: Preventive effect of artemether on schistosome infection. Chin Med J 1998, I I I:I23-127. 
38. Utzinger J, Xiao SH, Tanner M, Keiser J: Artemisinins for schistosomiasis and beyond. Curr Opin Investig Drugs 2007, 8: I05-II6.

39. Dai JR, Zhou XN, Liang YS, Zhang YP, Jiang YJ, Xi WP, Huang YX Chen C, Huang MX, Zhu YC: Sensitivity of Oncomelania snails to niclosamide in China. Zhongguo Ji Sheng Chong Xue Yu Ji Sheng Chong Bing Za Zhi 2002, 20(2): $101-105$.

40. Li HJ, Liang YS, Dai JR, Xu YL, Tang JX, Ru WW, Shen XH, Xu M, Zhu YC: $\mathbf{2 5 \%}$ concentrate suspension of niclosamide; Schistosome japonicum; cercariae; effective concentration. Chin J Schisto Cont 2005, 17:424-426.

4I. Wang ZC: Cost-effectiveness analysis of eliminating Oncomelania with $\mathbf{4 \%}$ niclosamide ethanolamine salt. J Public Health Prev Med 2006, I 7:40-44.

42. Chen ZP, Tao HQ, Hua DS, Shen BR, Chan HL: Evaluation of molluscicidal effect of nicotinanilide against Oncomelania snail. Zhongguo Ji Sheng Chong Xue Yu Ji Sheng Chong Bing Za Zhi I99I, 9(3):2।6-2|8.

43. Wu F, Chen YT, Dai JR, Gao ZH, Cao Q: The molluscicidal effect of bromoacetamide on Oncomelania snails. Chin J Schisto Cont |993, I:87-9|

44. Wu F, jiang YJ, Xi WP, Hong QB: Study on the long-term molluscicidal effect of magnesium powder. Chin J Parasit Dis Cont 2004, 17:356-357.

45. Zhu D, Zhou XN, Zhang SQ, Zhang GH, Liu HX, Lu DB, Cai GY, Ni QZ, Cao ZG, Wu WD: Study on the molluscicidal effect of META-Li against Oncomelania hupensis. Zhongguo Ji Sheng Chong Xue Yu Ji Sheng Chong Bing Za Zhi 2006, 24(3):200-203.

46. Xu XJ, Cai SX, Wei FH, Liu JB, Fu Y, Cao MM: Study on increasing molluscicidal effect by complex nicotinanilide with niclosamide. Chin J Schisto Cont 2003, 15:45-48.

47. Hong QB, Zhou XN, Han Y, P. SL, Yang G]: Molluscicidal effects of extracts of Eucalyptus camaldulensis on Oncomelania hupensis. Chin J Schisto Cont 200I, 13:18-20.

48. Yang Z, Yin GL, Fan CZ, Wang SW, Luo TP, Liu YH, Duan YC, Chen JX, Li YL: Molluscicidal effects of extracts of Jatropha curcas seeds on Oncomelania hupensis. Chin J Schisto Cont 2003, 15:364-366.

49. Liao BR, Wang WX, Zhang JL, Zhang Y, Hou JH, Shu LH: Studies on the molluscicidal activity of Leonurus artemisia to Oncomelania hupensis. Biotechnol Bull 2006, I 3:403-4I I.

50. Zuo JZ, Ren MY, He HB, Gao JX, Huang CL, Lin B, Hu SG: Control of schistosomiasis in lake regions through snail control and environmental measures. Chin / Schisto Cont 1999, I I: | 46- I 48.

5I. Gao LL: Considerations on snail control by environmental modification in Zhejiang province. Chin / Schisto Cont 2002, I 4:299-230

52. Wang JG, Liao HY, Zhong GT, Yu BG, Huang SS: Observation on the effect on schistosomiasis through snail control by environmental modification. Chin J Schisto Cont 2002, 14:200-202.

53. Zhang YQ, Zhang J, Shu RR, He QX, Qi LJ, Zhang R, Hu HJ, Shun WS Yang $\mathrm{H}$ : Effect of schistosomiasis control by environment alteration and chemotherapy in lake regions. Chin J Schisto Cont 2003, I5:304-305.

54. Li YS, Raso G, Zhao ZY, He YK, Ellis MK, McManus DP: Large water management projects and schistosomiasis control, Dongting Lake region, China. Emerg Infect Dis 2007, 13:973-979.

55. Jia DY: The epidemiology and control strategy of schistosome recently in China. Chin J Cont Endem Dis 1993, 6:65-67.

56. Yao JM, Su YX, Su ZD, Deng JM, Zeng LD, Li CM: The importance of health education for schistosomiasis control. Chin J Schisto Cont 1995, 7:368-369.

57. Liu HX, Yu FG, Yang XQ: The role of health education to improve schistosomiasis screening in human. Pract Prev Med 1998, 5:334.

58. Zhen J: The challenge and development aim of schistosomiasis control in China. J Trop Dis Parasitol 2004, 2:193-197.

59. Zhen J: Schistosomiasis control and its prospect in China. Chin J Schisto Cont 2006, 15:1-2.

60. Lin DD, Wu HW, Wu GL, Zhou XN: Review and evaluation on optimal combined strategies for schistosomiasis control in China. Chin J Schisto Cont 2007, 19:234-237.

61. Zhou XN, Jiang QW, Shun LM, Wang TP, Hong QB, Zhao GM, Lin DD: Schistosomiasis control and surveillance in China. Chin J Schisto Cont 2005, 17:161-165.

62. Wang LD: Carry out ordinance, change the policy of schistosomiasis control. Chin J Prev Med 2006, 40:219-220.
63. Smith R: Chinese medical journals: getting in touch. BM] 1994 309:74.

64. Gastel B, Weng YQ: Medical journals in China. Ann Intern Med 1990, I | 2:70-72.

65. Ren S, Liang P, Zu G: The challenge for Chinese scientific journals. Science 1999, 286:1683.

Publish with BioMed Central and every scientist can read your work free of charge

"BioMed Central will be the most significant development for disseminating the results of biomedical research in our lifetime. "

Sir Paul Nurse, Cancer Research UK

Your research papers will be:

- available free of charge to the entire biomedical community

- peer reviewed and published immediately upon acceptance

- cited in PubMed and archived on PubMed Central

- yours - you keep the copyright 